\title{
15. STRONTIUM ISOTOPE AND BENTHIC FORAMINIFER STABLE ISOTOPE RESULTS FROM OLIGOCENE SEDIMENTS AT SITE 803 ${ }^{1}$
}

\author{
Enriqueta Barrera, ${ }^{2,3}$ Jack Baldauf, ${ }^{4}$ and Kyger C Lohmann ${ }^{2}$
}

\begin{abstract}
Stratigraphic information from strontium, oxygen, and carbon isotopic ratios has been integrated with diatom and planktonic foraminifer datums to refine the Oligocene to early Miocene chemostratigraphy of Site 803. The $\mathrm{Sr}$ isotope results are based on analyses of mixed species of planktonic foraminifer and bulk carbonate samples. ${ }^{87} \mathrm{Sr} /{ }^{86} \mathrm{Sr}$ ratios of bulk carbonate samples are, in most cases, less radiogenic than contemporaneous seawater. Estimated sediment ages based on planktonic foraminifer ${ }^{87} \mathrm{Sr} /{ }^{86} \mathrm{Sr}$ ratios, using the Sr-isotope-age relation determined by Hess and others in 1989, are in moderately good agreement with the biostratigraphic ages. Chronological resolution is significantly enhanced with the correlation of oxygen and carbon isotope records to those of the standard Oligocene section tied to the Geomagnetic Polarity Time Scale at Site 522. Ages revised by this method and other published ages of planktonic foraminifer datums are used to revise the Oligocene stratigraphy of Site 77 to correlate the stable isotope records of Sites 77 and 803.

Comparison of the Cibicidoides stable isotope records of Sites 77 and 574 with paleodepths below $2500 \mathrm{~m}$ in the central equatorial Pacific, and Site 803 at about 2000-m paleodepth in the Ontong Java Plateau reveals inversions in the vertical $\delta^{18} \mathrm{O}$ gradient at several times during the Oligocene and in the early Miocene. The shallower water site had significantly.higher $\delta^{18} \mathrm{O}$ values than the deeper water sites after the earliest Oligocene ${ }^{18} \mathrm{O}$ enrichment and before $34.5 \mathrm{Ma}$, in the late Oligocene from 27.5 to at least $25 \mathrm{Ma}$, and in the early Miocene from 22.5 to $20.5 \mathrm{Ma}$. It is not possible to ascertain if the $\delta^{18} \mathrm{O}$ inversion persisted during the Oligocene/Miocene transition because the deeper sites have hiatuses spanning this interval. We interpret this pattern to reflect that waters at about $2000 \mathrm{~m}$ depth were cold and may have formed from mixing with colder waters originating in northern or southern high-latitude regions. The deeper water appear to have been warmer and may have been a mixture with warm saline waters from mid- or low-latitude regions. No apparent vertical $\delta^{13} \mathrm{C}$ gradient is present during the Oligocene, suggesting that the age difference of these water masses was small.
\end{abstract}

\section{INTRODUCTION}

One of the objectives of Ocean Drilling Program (ODP) Leg 130 was the documentation of major global climatic events and paleoceanographic changes in Pacific deep waters during the Neogene and Paleogene. Five sites (Sites 803-807) were drilled in a depth transect on the northeastern side of the Ontong Java Plateau (Fig. 1). The plateau was located in the southern middle latitudes during the Cretaceous, but it had migrated to near the equator by Oligocene time (Hammond et al., 1975). High carbonate flux and sedimentation rates during the late Paleogene and Neogene provide expanded sedimentary records and the opportunity for detailed studies of oceanographic events. The deep-water Site 803 (latitude $2^{\circ} 26.0^{\prime} \mathrm{N}$, longitude $160^{\circ} 32.4^{\prime} \mathrm{E}$ ), located in $3410 \mathrm{~m}$ of water, is the only Leg 130 drill hole with nearly complete recovery of a thick section (about $200 \mathrm{~m}$ ) of Oligocene sediments. A thicker $(\sim 300 \mathrm{~m})$ Oligocene section at water depths of $2200 \mathrm{~m}$ on the crest of the plateau had been recovered during Deep Sea Drilling Project (DSDP) Leg 30 at Site 289. However, unlike the section at Site 803 , this section contains a major hiatus spanning from the late Eocene into the early Oligocene. In this report, we use oxygen and carbon isotope ratios of the benthic foraminifer genus Cibicidoides spp. from Site 803 to reconstruct the evolution of deep waters at this location during the Oligocene. Strontium ( $\mathrm{Sr}$ ) isotope ratios of planktonic foraminifer and bulk carbonate samples have been integrated with benthic foraminifer stable isotope results and biostratigraphic data to develop an Oligocene chemostratigraphy for Site 803 .

\footnotetext{
'Berger, W.H., Kroenke, L.W., Mayer, L.A., et al., 1993. Proc. ODP, Sci. Results, 130: College Station, TX (Ocean Drilling Program). U.S.A

${ }^{2}$ Department of Geological Sciences, University of Michigan, Ann Arbor, MI 48103,

${ }^{3}$ Present address: Department of Geological and Geophysical Sciences, Princeton University, Princeton, N.J. 08544, U.S.A.

${ }^{4}$ Ocean Drilling Program, Texas A\&M University, 1000 Discovery Drive, College Station, TX 77845-9547, U.S.A.
}

It has been suggested that, before high-latitude cooling occurred, deep and bottom waters formed by the sinking of warm saline plumes produced by evaporation in low- and mid-latitude shelf areas (Chamberlain, 1906; Brass et al., 1982). Recently, Kennett and Stott (1990) have suggested that Eocene and Oligocene deep-water circulation may have been substantially different from that of the late Neogene. They propose, based on benthic foraminifer $\delta^{18} \mathrm{O}$ values from two sites in the southern South Atlantic, that deep waters at intermediate depths were of Antarctic origin and colder than deeper waters that originated in the low latitudes. Barrera and Huber (1991) noted that, after the earliest Oligocene positive $\delta^{18} \mathrm{O}$ shift, benthic foraminifer records between 2000 and $3000 \mathrm{~m}$ water depths from high-latitude sites are offset by $\sim 0.5 \%$ from those of lower latitude Pacific and Atlantic sites. They also suggest that Oligocene thermohaline circulation must have been different from the present and that lower latitude deep waters may have been mixtures of waters from at least two sources. The isotopic data of Site 803 generated in this study permit us to explore this possibility further. The paleodepth of Site 803 has been estimated at about $2000 \mathrm{~m}$ during the earliest Oligocene using normal subsidence rates for oceanic crust (Detrick et al., 1977). In this study, comparison of the isotopic records of Site 803 with those of central equatorial Pacific DSDP Sites 77 and 574 at paleodepths between 2600 and 3100 $\mathrm{m}$ reveals significantly higher $\delta^{18} \mathrm{O}$ values in the shallower water site between $36-35 \mathrm{Ma}, 28.5-25 \mathrm{Ma}$, and $22.5-20.5 \mathrm{Ma}$. Assuming that the paleodepth estimate of Detrick et al. (1977) is correct, we suggest that the apparent inversion of the vertical $\delta^{18} \mathrm{O}$ gradient relative to Neogene oceanic patterns may reflect warmer and saline waters below $2600 \mathrm{~m}$ capped by colder deep waters.

Before drawing inferences from the stable isotopic records, we developed a chemobiostratigraphy for the Oligocene-lower Miocene section at Site 803. This was done based on estimated sediment ages from (1) planktonic foraminifer ${ }^{87} \mathrm{Sr} /{ }^{86} \mathrm{Sr}$ ratios using the $\mathrm{Sr}$ isotope-age relation of Hess et al. (1989); (2) ages of planktonic foraminifer (Leckie, this volume) and nannofossil (Backman, this volume) datums according to the chronology of Berggren et al. 


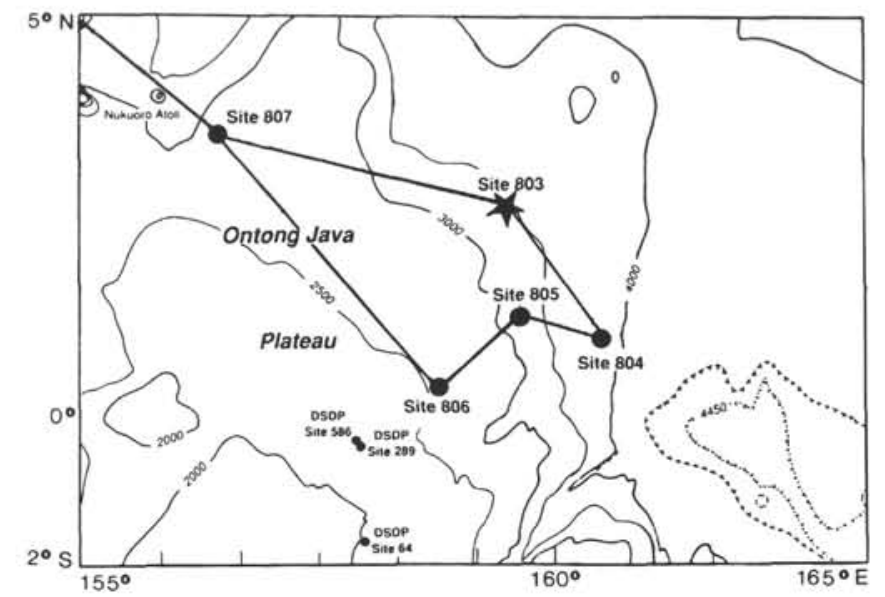

Figure 1. Location of Site 803 on the Ontong Java Plateau and other sites drilled during Leg 130 together with those from DSDP Legs 7, 30, and 89. Contour interval is in meters.

(1985); and (3) correlation of stable isotope records of Sites 803 with those of DSDP Site 522, which is tied to the Geomagnetic Polarity Time Scale (GPTS). In Oligocene sections, high chronological control from the biostratigraphy alone is difficult because biozonations are relatively long. Moreover, biostratigraphic datums can exhibit considerable diachroneity across latitude and longitude (Keller, 1983). This difficulty can, in part, be overcome using an integrated stratigraphy based on faunal and floral datums, and stable oxygen and carbon, and $\mathrm{Sr}$ isotopes. The $\mathrm{Sr}$-isotope technique is a powerful tool for correlation of Oligocene deep-sea sequences because the residence of $\mathrm{Sr}$ in seawater is several million years, but the ${ }^{87} \mathrm{Sr}{ }^{86} \mathrm{Sr}$ ratio of seawater changed rapidly and nearly monotonically in the Oligocene and early Miocene (Burke et al., 1982). Stable isotope records of benthic foraminifers from globally distributed sequences show pronounced and apparently synchronous variations during the Oligocene. Correlation of isotopic variations among sites provides an independent chronological control. The integration of $\mathrm{Sr}$-isotope data with stable isotope and biostratigraphic data has allowed more precise absolute dating of this section than the use of one of these techniques alone.

\section{BACKGROUND}

\section{Strontium Isotopes}

The ${ }^{87} \mathrm{Sr} /{ }^{86} \mathrm{Sr}$ ratio of seawater is determined by the proportion of $\mathrm{Sr}$ entering the ocean from three sources that have very characteristic ratios: the fluvial or weathering flux, the hydrothermal flux, and the diagenetic flux of Sr from deep-sea sediments (Elderfield, 1986). Because the residence time of $\mathrm{Sr}$ in the ocean has been estimated at about 5 m.y., whereas the ocean mixes in approximately $1000 \mathrm{yr}$ (Broecker and Peng, 1982), the ${ }^{87} \mathrm{Sr}{ }^{86} \mathrm{Sr}$ ratio of seawater is uniform at a given time. Burke et al. (1982) published the first detailed record for the Cenozoic and the entire Phanerozoic from analyses of bulk samples, which included carbonates, evaporites, and phosphates. From these data, it was evident that rapid and apparent monotonic increase in seawater ${ }^{87} \mathrm{Sr} /{ }^{86} \mathrm{Sr}$ occurred in the second half of the Cenozoic, with little variation in the older part of the Cenozoic. Further refinement of the Cenozoic record has revealed that the highest chronologic resolution can be obtained with samples from Oligocene and early Miocene time because of the rapid rate of increase in the ${ }^{87} \mathrm{Sr} /{ }^{86} \mathrm{Sr}$ ratio of the oceans during that time (DePaolo and Ingram, 1985; Palmer and Elderfield, 1985; DePaolo, 1986; Hess et al., 1986; Miller et al., 1988). The first two ${ }^{87} \mathrm{Sr}{ }^{86} \mathrm{Sr}$ records calibrated directly to the GPTS were those for the Oligocene sections of Contessa Quarry (DePaolo and Ingram, 1986) and DSDP Site 522 (Miller et al., 1988). Recently, Hess et al. (1989) have presented ${ }^{87} \mathrm{Sr} /{ }^{\beta 6} \mathrm{Sr}$ data of well-preserved planktonic foraminifers from the lower Miocene and Oligocene sections at DSDP Sites 516 and 563, which are two of the four sites with magnetostratigraphy on which Berggren et al. (1985) elaborated their magnetobiostratigraphic model. The data from these two sites reveal that the rate of change of ${ }^{87} \mathrm{Sr} /{ }^{86} \mathrm{Sr}$ increased at about $27 \mathrm{Ma}$ and did not vary during the rest of the late Oligocene and early Miocene, as previously suggested by Miller et al. (1988). Equations derived from the two relations of ${ }^{87} \mathrm{Sr} /{ }^{86} \mathrm{Sr}$ and age have been used by Hess et al. (1989) to estimate ages of sediments at Pacific DSDP Sites 77, 292, and 593 and Atlantic DSDP Site 529 (without magnetostratigraphy), and to determine from these data the synchroneity of biostratigraphic datums oceanwide across longitude.

Some of the above studies generated ${ }^{87} \mathrm{Sr} /{ }^{86} \mathrm{Sr}$ records based on analyses of bulk carbonate (Burke et al., 1982; DePaolo, 1986), whereas more recent studies have analyzed foraminifers (Elderfield et al., 1982; Palmer and Elderfield, 1985; Hess et al., 1986; Miller et al., 1988; Capo and DePaolo, 1990; DePaolo and Finger, 1991). No comparisons have been made between $\mathrm{Sr}$-isotope data from foraminifers and bulk carbonates from the same sequence, although this is important for the evaluation of results from sections where the low abundance of foraminifers precludes their analysis. It is possible that a significant difference exists between the $\mathrm{Sr}$-isotope ratios of foraminifers and bulk carbonate components resulting from differential diagenetic alteration and exchange with pore waters, which would give rise to differences in inferred sediment ages (Richter and DePaolo, 1987). In this study, we compare these data and find the results from the foraminifer analyses to be more reliable.

\section{Oxygen and Carbon Isotopes}

Stratigraphic correlations using oxygen and carbon isotope compositions of biogenic carbonate have been successfully applied to many deep-sea sequences (Miller and Thomas, 1985; Miller et al., 1985, 1988). This technique, which depends upon matching patterns of $\delta^{13} \mathrm{C}$ and $\delta^{18} \mathrm{O}$ change, is particularly suitable for Oligocene sediments because stable isotope records of benthic foraminifers from sequences at Pacific, Atlantic, and Indian ocean deep-sea sites show pronounced synchronous variations. A ubiquitous increase in benthic foraminifer $\delta^{18} \mathrm{O}$ values of about $1 \%$ to $1.5 \%$ has been observed in the earliest Oligocene within Chron C13N in sediments dated between 35.9 and $35.5 \mathrm{Ma}$ at Site 522 (Poore and Matthews, 1984; Oberhänsli et al., 1984; Miller et al., 1988) and at ODP Site 744 (Barrera and Huber, 1991; Barrera et al., 1991). This isotopic event is interpreted to reflect both high-latitude cooling and increased ice volume (Keigwin, 1980; Keigwin and Keller, 1984; Miller and Thomas, 1985; Keigwin and Corliss, 1986). After the earliest Oligocene $\delta^{18} \mathrm{O}$ increase, the record of ODP Sites 689 and 744 shows that deep-water benthic foraminifer $\delta^{18} \mathrm{O}$ in the southern high latitudes remained relatively high during the early Oligocene, whereas benthic foraminifer $\delta^{18} \mathrm{O}$ values from the lower latitude sites (i.e., Site 522) decreased and remained low for most of the Oligocene (Barrera and Huber, 1991). In the middle Oligocene, $\delta^{18} \mathrm{O}$ values increased at both high- and low-latitude locations in sediments corresponding to Magnetochrons $\mathrm{C} 11$ and $\mathrm{C} 9$ (Miller et al., 1988). This isotopic increase has also been interpreted to reflect increased ice volume (Keigwin and Keller, 1984; Miller and Thomas, 1985; Miller et al., 1987). At most sites, this event is not recorded because of a hiatus or interval of carbonate dissolution (Keller et al., 1987; Barrera et al., 1991).

Oligocene and early Miocene $\delta^{13} \mathrm{C}$ trends in benthic foraminifers are global and are likewise observed in planktonic foraminifer data (Shackleton and Hall, 1984). In the early Oligocene, benthic foraminifer $\delta^{13} \mathrm{C}$ values at many sites increased sharply, coinciding with the $\delta^{18} \mathrm{O}$ shift (Oberhänsli et al., 1984; Miller et al., 1987; Barrera and Huber, 1991). Following this event, $\delta^{13} \mathrm{C}$ values progressively decreased during the early Oligocene to attain the lowest values in the middle Oligocene (Miller et al., 1988). In the latest Oligocene, both $\delta^{13} \mathrm{C}$ and $\delta^{18} \mathrm{O}$ values increased rapidly just preceding the first appearance of Globorotalia kugleri, which marks the Oligocene/Miocene boundary, and then decreased sharply in the earliest Miocene (Miller and Fairbanks, 
1985; Miller et al., 1985, 1988). This event has been estimated between 23.5 and 24.3 Ma (Miller et al., 1988).

\section{MATERIALS AND METHODS}

Sediment samples $\left(\sim 5 \mathrm{~cm}^{3}\right.$ volume) were divided into two portions. A sediment portion $(\sim 1 \mathrm{mg})$ of bulk carbonate was dried in an oven for $24 \mathrm{hr}$ and reserved for $\mathrm{Sr}$-isotope analysis. The remainder of the sample was disaggregated in tap water, washed over a $150-\mu \mathrm{m}$ screen, collected in filter paper, and dried in an oven at $<50^{\circ} \mathrm{C}$. Samples for $\mathrm{Sr}$-isotope analysis and $\mathrm{Ca}, \mathrm{Sr}$, and $\mathrm{Mg}$ concentrations consisted of specimens $>150 \mu \mathrm{m}$ of mixed species of planktonic foraminifers. Individual planktonic foraminifer species were not analyzed because the number of specimens was too low in most samples. Oxygen and carbon isotope analyses were of specimens $>150 \mu \mathrm{m}$ of the benthic foraminifer genus Cibicidoides.

Foraminifer tests were fractured with a sharp needle, and adhering or infilling fine-grained material was removed by ultrasonic agitation of test fragments in distilled water. After each rinse, the supernatant was pipetted out. The effectiveness of the procedure was verified with observations of chamber surfaces under the binocular microscope. Measurement of $\mathrm{Sr}, \mathrm{Mg}$, and $\mathrm{Ca}$ elemental concentrations were conducted at the Inorganic Geochemistry Laboratory of the University of Michigan (Ann Arbor, MI). Dry samples between 100 and $50 \mu \mathrm{g}$ were reacted with $10 \% \mathrm{HCl}$, and the solution was analyzed by simultaneous mode in a Leemans Lab Inc. Plasma-Spec (ICP-AES) III Model. The precision of duplicate samples was better than $5 \%$.

Sr-isotope analyses of most bulk carbonate samples were performed at the Mobil Research and Development Corporation (Dallas, TX) following the procedures described in Koepnick et al. (1990). Sr-isotope analyses of all the foraminifer samples and a few bulk carbonate were conducted at Washington University (St. Louis, MI) according to the techniques outlined in Podosek et al. (1991). Sr-isotope ratios (Table 1) from both laboratories are normalized relative to a value of 0.71014 for the NBS-987 standard. The analytical uncertainty of the measurements are $2 \sigma$ (Table 1 ). For comparison of data from these laboratories, we follow the delta $(\delta)$ notation proposed by Hess et al. (1986), in which

$$
\delta^{87} \mathrm{Sr}=\left[\frac{{ }^{87} \mathrm{Sr} /{ }^{86} \mathrm{Sr} \text { sample }}{{ }^{87} \mathrm{Sr} /{ }^{86} \mathrm{Sr} \text { seawater }}\right]-1 \times 10^{5},
$$

and the ${ }^{87} \mathrm{Sr} /{ }^{86} \mathrm{Sr}$ seawater is the strontium isotope composition of modern seawater. The ratio of modern seawater is 0.709073 at the Mobil laboratory, and 0.709067 at Washington University. The $\delta$ values are 100,000 deviations from modern seawater. Absolute ages for Site 803 were calculated using the equation of Hess et al. (1989);

$$
\mathrm{t}=-0.24742 \delta^{87} \mathrm{Sr}-10.95385
$$

for samples older than $27 \mathrm{Ma}$ (between $\delta^{87} \mathrm{Sr}=195.4$ to -152.0 ) and,

$$
\mathrm{t}=-0.14359 \delta^{87} \mathrm{Sr}+4.92651
$$

for samples younger than $27 \mathrm{Ma}$ (between $\delta^{87} \mathrm{Sr}=-152.0$ to -84.3 ). Age uncertainty is $\pm 0.38 \mathrm{~m}$.y. for the first equation and $\pm 0.31 \mathrm{~m}$.y. for the second equation, assuming an analytical uncertainty of 2-3 units of the $\delta^{87} \mathrm{Sr}$ value (Hess et al., 1989).

Oxygen and carbon isotope ratios of species of Cibicidoides were measured at the Stable Isotope Laboratory of the University of Michigan. Before being analyzed samples were roasted at $380^{\circ} \mathrm{C}$ for $1 \mathrm{hr}$ to remove volatile organic contaminants. Analyses are reported in $\delta$ notation as per mil deviations from the Peedee Belemnite (PDB) standard. Samples were reacted individually at $73^{\circ} \mathrm{C}$ in an automated Kiel carbonate extraction system coupled directly to a Finnigan 251 mass spectrometer. Isotopic measurements were made relative to a laboratory standard $\mathrm{CO}_{2}$, which is calibrated to international standards through analysis of NBS-18, NBS-19, and NBS-20 powdered carbonate standards. Standard replicates have a precision of $\pm 0.05 \%$ for $\delta^{18} \mathrm{O}$ and $\delta^{13} \mathrm{C}$. The $\delta^{18} \mathrm{O}$ values of modern specimens of the genus Cibicidoides appear to depart from equilibrium values by about $0.5 \%-0.65 \%$, whereas $\delta^{13} \mathrm{C}$ values appear to reflect that of the dissolved total $\mathrm{CO}_{2}$ in seawater (Belanger et al., 1981; Graham et al., 1981).

\section{SITE LITHOLOGY}

At Hole 803D, sediments in the lower Miocene to Oligocene section are nannofossil chalk and nannofossil chalk with foraminifers, varying in carbonate abundance between approximately $95 \%$ and $85 \%$. The transition from ooze to chalk occurs at shallower depths (about $217 \mathrm{~m}$ ) within middle Miocene sediments. In the lower Miocene to Oligocene part of the section, the relative abundance of either biogenic silica or foraminifers is only a few percent. The relative abundance of diatoms does not increase significantly with depth, but the preservation of the assemblage decreases in the deeper and more indurated sediments. In contrast, foraminifer abundance increases to values higher than $10 \%$ in the lowermost part of the sequence (Cores 130-803D-57X through -59X; 525-554 mbsf), spanning the Eocene-Oligocene transition. Throughout the entire section, the content of clay and other nonbiogenic components is negligible (Shipboard Scientific Party, 1991).

\section{PRESERVATION OF BIOGENIC CALCITE AND ISOTOPIC RATIOS}

Dissolution and reprecipitation processes in biogenic calcite can significantly modify the original $\mathrm{Sr}$-isotope composition if pore waters have received $\mathrm{Sr}$ from a source with a ${ }^{87} \mathrm{Sr} /{ }^{86} \mathrm{Sr}$ ratio very different from that of the calcite. Secondary calcite replacement in pore waters with ${ }^{87} \mathrm{Sr} /{ }^{86} \mathrm{Sr}$ ratios similar to those of coexisting calcite will cause little or no modification of the original calcite ${ }^{87} \mathrm{Sr} /{ }^{86} \mathrm{Sr}$ ratio. However, interstitial waters with ratios different from the coexisting carbonate can result from $\mathrm{Sr}$ input from (1) underlying basalt, (2) continental detritus or clay components with higher ${ }^{87} \mathrm{Sr}{ }^{86} \mathrm{Sr}$, (3) volcanic ash and glass with relatively low ${ }^{87} \mathrm{Sr} /{ }^{\beta 6} \mathrm{Sr}$ ratios (Elderfield and Gieskes, 1982; Gieskes et al., 1986), and (4) vertical migration of pore waters from older or younger carbonates within the sedimentary column. Consequently, in the assessment of the preservation of the original calcite ${ }^{87} \mathrm{Sr}{ }^{86} \mathrm{Sr}$ ratio, data on the ${ }^{87} \mathrm{Sr} /{ }^{86} \mathrm{Sr}$ ratio of pore waters are important if evidence is present of recrystallization. Unfortunately, such data are not available for Site 803 .

The amount of secondary replacement or recrystallization in foraminifer tests can be evaluated by scanning electron microscope (SEM) inspection of the wall surfaces and microstructure. Preservation of foraminifer and nannofossil chemistry has also been inferred from $\mathrm{Sr} / \mathrm{Ca}$ ratios of pore waters and/or the foraminifer/nannofossil carbonate (Baker et al., 1982; Elderfield et al., 1982). According to the experimentally determined distribution coefficient of $\mathrm{Sr}$, inorganically precipitated calcite has lower $\mathrm{Sr} / \mathrm{Ca}$ ratios than biologically precipitated calcite (Katz et al., 1972; Baker et al., 1982; Carpenter and Lohmann, in press). Consequently, it is commonly inferred that $\mathrm{Sr} / \mathrm{Ca}$ ratios of foraminifer tests or nannofossil skeletons close to those measured in well-preserved specimens indicate little or no diagenetic alteration by dissolution-reprecipitation processes (Hess et al., 1986, 1989).

The SEM observations of planktonic and benthic foraminifer specimens in the lower Miocene-Oligocene section at Site 803 indicate that the amount of secondary calcite, as evidenced by the presence of small euhedral crystals on interior surfaces and on the wall microstructure, appears to be volumetrically small in relation to the whole. This is particularly the case for specimens of the benthic foraminifer Cibicidoides. Preservation of planktonic foraminifer tests was poor in samples from Core 135-803D-58X and below, but no measurements were made in this interval. The $\mathrm{Sr} / \mathrm{Ca}$ ratios of mixed planktonic foraminifer samples range from 1.45 to $1.16 \mathrm{mM} / \mathrm{M}$ (Table 1) with no distinctive trend. These values are 
Table 1. Stable and strontium isotope data of samples from the early Miocene to Oligocene section of Hole 803D.

\begin{tabular}{|c|c|c|c|c|c|c|c|c|c|c|c|c|c|}
\hline \multirow[b]{2}{*}{$\begin{array}{l}\text { Core, section, } \\
\text { interval }(\mathrm{cm})\end{array}$} & \multirow[b]{2}{*}{$\begin{array}{l}\text { Depth } \\
\text { (mbsf) }\end{array}$} & \multirow[b]{2}{*}{$\begin{array}{l}\text { Age } \\
(\mathrm{Ma})\end{array}$} & \multicolumn{2}{|c|}{ Cibicidoides spp. } & \multicolumn{5}{|c|}{ Mixed planktonic foraminifers } & \multicolumn{4}{|c|}{ Bulk carbonate } \\
\hline & & & $\delta^{18} \mathrm{O}$ & $\delta^{13} \mathrm{C}$ & $\mathrm{Sr} / \mathrm{Ca}$ & $\mathrm{Mg} / \mathrm{Ca}$ & ${ }^{87} \mathrm{Sr} /^{86} \mathrm{Sr}$ & $\delta^{87} \mathrm{Sr}$ & Age & ${ }^{87} \mathrm{Sr} /{ }^{86} \mathrm{Sr}$ & $\begin{array}{c}\text { Percent } \\
\text { insoluble }\end{array}$ & $\delta^{87} \mathrm{Sr}$ & Age \\
\hline \multicolumn{14}{|l|}{ 130-803D- } \\
\hline $27 X-2,114-116$ & 239.15 & 16.60 & 1.49 & 1.62 & & & & & & & & & \\
\hline $28 \mathrm{X}-2,118-120$ & 248.59 & 20.00 & 1.84 & 0.82 & & & & & & & & & \\
\hline $28 X-4,118-120$ & 251.59 & 20.15 & 1.85 & 0.89 & & & & & & & & & \\
\hline $29 X-2,71-73$ & 257.72 & 20.47 & 1.65 & 1.08 & & & & & & & & & \\
\hline $29 X-4,42-44$ & 260.43 & 20.61 & 2.00 & 1.16 & & & & & & & & & \\
\hline $30 \times-2,67-69$ & 267.28 & 20.96 & 1.51 & 1.03 & & & & & & & & & \\
\hline $30 X-4,40-42$ & 270.01 & 21.10 & 1.54 & 0.80 & & & & & & & & & \\
\hline $31 X-1,44-46$ & 275.15 & 21.36 & 1.78 & 0.72 & & & & & & & & & \\
\hline $31 X-2,17-19$ & 276.38 & 21.42 & 1.98 & 1.25 & & & & & & & & & \\
\hline $31 X-3,120-124$ & 278.92 & 21.55 & 1.59 & 0.79 & & & & & & & & & \\
\hline $31 \times-4,35-37$ & 279.55 & 21.59 & 2.19 & 0.91 & & & & & & & & & \\
\hline $32 X-1,48-50$ & 284.78 & 21.86 & 2.14 & 1.12 & & & & & & & & & \\
\hline $32 X-3,54-56$ & 287.85 & 22.01 & 1.98 & 1.00 & & & & & & & & & \\
\hline $32 X-4,34-36$ & 289.14 & 22.08 & & & & & & & & $0.708219 \pm 23$ & 6.2 & -120.44 & 22.2 \\
\hline $33 X-1,35-37$ & 294.45 & 22.35 & 1.81 & 0.46 & & & & & & & & & \\
\hline $33 X-2,105-107$ & 296.66 & 22.46 & 1.60 & 0.83 & & & & & & & & & \\
\hline $33 X-4,109-111$ & 299.69 & 22.62 & 1.85 & 1.39 & & & & & & & & & \\
\hline $34 X-1,66-68$ & 303.96 & 22.84 & 1.71 & 1.59 & & & & & & & & & \\
\hline $34 X-1,110-114$ & 304.42 & 22.86 & 1.92 & 1.16 & & & & & & & & & \\
\hline $34 X-4,67-69$ & 308.47 & 23.07 & 2.10 & 1.61 & & & & & & $0.708038 \pm 19$ & 17.6 & -145.97 & 25.9 \\
\hline $35 X-1,42-44$ & 313.42 & 23.32 & 1.89 & 1.36 & 1.32 & 3.41 & $0.708160 \pm 20$ & -127.91 & 23.3 & & & & \\
\hline $35 \times-4,77-79$ & 318.27 & 23.57 & 1.95 & 1.56 & 1.30 & 3.36 & $0.708150 \pm 20$ & -129.32 & 23.5 & $0.708159 \pm 20$ & 20.2 & -128.90 & 23.4 \\
\hline $35 X-5,18-20$ & 319.19 & 23.62 & 2.24 & 1.62 & & & & & & & & & \\
\hline $35 X-6,75-77$ & 321.26 & 23.74 & 2.05 & 1.30 & & & & & & & & & \\
\hline $36 \mathrm{X}-1,101-103$ & 323.71 & 23.97 & 1.43 & 0.66 & & & & & & & & & \\
\hline $36 x-3,67-69$ & 326.38 & 24.20 & 1.32 & 0.83 & & & & & & & & & \\
\hline $37 X-1,82-84$ & 333.12 & 24.77 & 1.43 & 0.65 & & & & & & & & & \\
\hline $37 X-3,67-69$ & 335.98 & 25.01 & 1.57 & 0.83 & & & & & & & & & \\
\hline $37 X-5,41-43$ & 338.72 & 25.25 & 1.56 & 0.76 & & & & & & & & & \\
\hline $38 \mathrm{X}-1,44-46$ & 342.44 & 25.53 & 1.83 & 0.97 & & & & & & $0.708057 \pm 27$ & 18.9 & -143.29 & 25.5 \\
\hline $39 X-1,57-59$ & 352.17 & 25.93 & 1.92 & 0.77 & & & & & & & & & \\
\hline $39 X-4,38-40$ & 356.48 & 26.11 & 2.25 & 0.50 & & & & & & $* 0.708024 \pm 20$ & & -147.09 & 26.1 \\
\hline $40 X-1,61-63$ & 361.91 & 26.36 & 1.89 & 0.91 & & & & & & & & & \\
\hline $40 \times-4,37-39$ & 366.17 & 26.73 & 2.28 & 0.81 & & & & & & $0.707932 \pm 21$ & 19.5 & -160.91 & 28.9 \\
\hline $41 X-1,90-92$ & 371.91 & 27.23 & 2.25 & 0.82 & & & & & & & & & \\
\hline $42 X-2,68-70$ & 382.88 & 28.19 & 2.04 & 0.89 & & & & & & $0.708007 \pm 29$ & 17.9 & -150.34 & 26.3 \\
\hline $42 X-3,33-35$ & 384.04 & 28.24 & 1.88 & 0.88 & & & & & & & & & \\
\hline $42 X-5,34-36$ & 387.05 & 28.38 & 1.80 & 0.68 & & & & & & & & & \\
\hline $43 \mathrm{X}-1,51-53$ & 390.91 & 28.54 & 1.73 & 0.46 & 1.45 & 3.18 & $0.707970 \pm 20$ & -154.71 & 27.3 & $0.708027 \pm 27$ & 21.7 & -147.52 & 25.5 \\
\hline $43 X-4,86-88$ & 395.76 & 28.76 & 1.67 & 0.76 & 1.38 & 3.30 & & & & & & & \\
\hline $44 X-1,77-79$ & 400.75 & 28.97 & 2.07 & 0.38 & & & & & & & & & \\
\hline $44 X-2,33-35$ & 401.83 & 29.02 & 1.63 & 0.45 & & & & & & & & & \\
\hline $44 X-4,12-14$ & 404.62 & 29.14 & 2.11 & 0.52 & & & $0.707886 \pm 20$ & -166.56 & 30.3 & $* 0.707891 \pm 20$ & & -165.85 & 30.1 \\
\hline $44 X-5,20-22$ & 406.20 & 28.21 & 1.75 & 0.54 & & & & & & & & & \\
\hline $45 X-1,31-33$ & 410.01 & 29.38 & 1.87 & 0.84 & 1.44 & 2.55 & $0.707890 \pm 20$ & -165.99 & 30.1 & $0.707869 \pm 10$ & 18.2 & -169.80 & 31.1 \\
\hline $45 X-2,31-33$ & 411.51 & 29.44 & 1.96 & 0.70 & & & & & & & & & \\
\hline $45 X-3,21-23$ & 412.91 & 29.50 & 1.92 & 0.13 & & & & & & & & & \\
\hline $45 X-5,38-40$ & 416.08 & 29.64 & 1.30 & 0.39 & 1.27 & 3.10 & $0.707890 \pm 20$ & -165.99 & 30.1 & & & & \\
\hline
\end{tabular}

either slightly lower or in the range of those measured in modern planktonic foraminifers from tropical regions (Delaney et al., 1985), suggesting either minor or no modification of planktonic foraminifer Sr concentrations.

The $\mathrm{Sr} / \mathrm{Ca}$ ratios of bulk carbonate sediments at Site 803 have been measured by Delaney and Linn (this volume). These ratios are more variable and, on average, are significantly higher than those of mixed species of planktonic foraminifers. They range between 1.4 and 1.82 $\mathrm{mM} / \mathrm{M}$. Such a composition is expected as nannofossils, which are the most abundant constituent in these sediments, have higher $\mathrm{Sr}$ concentrations by about $200 \mathrm{ppm}$ than foraminifers (Morrow and Mayers, 1978). Moreover, Delaney and Linn (this volume) report that $\mathrm{Sr} / \mathrm{Ca}$ ratios of bulk carbonates from Leg 130 sites, including Site 803 , vary as a function of sediment age and exhibit the same pattern as that of well-preserved planktonic foraminifers for the last 40 m.y. (Graham et al., 1982). Based on these observations, Delaney and Linn (this volume) have concluded that measured bulk carbonate $\mathrm{Sr} / \mathrm{Ca}$ ratios at these sites reflect primary carbonate chemistries. Nevertheless, ${ }^{87} \mathrm{Sr} /{ }^{86} \mathrm{Sr}$ ratios of foraminifers and bulk carbonate discussed below show significant discrepancies at various levels at Site 803 (Fig. 2 and Table 1). This indicates that either one, or in some instances both, of these carbonate components have incorporated $\mathrm{Sr}$ from sediment sources with $\mathrm{Sr}$-isotope compositions different from that of contemporaneous seawater. The high percentage of insoluble residues after the dissolution of bulk carbonate samples (Table 1) makes these data suspect. Some samples could have incorporated $\mathrm{Sr}$ from the noncarbonate sources (Koepnick et al., 1990). The consistency of the planktonic foraminifer ${ }^{87} \mathrm{Sr} /{ }^{86} \mathrm{Sr}$ results and the apparent lack of textural evidence for major secondary calcite replacement features suggest that foraminifer data reflect contemporaneous seawater more closely.

No textural evidence is present to suggest that $\delta^{18} \mathrm{O}$ compositions of Cibicidoides have been greatly affected by diagenetic processes. The similarity of Site 803 data with $\delta^{18} \mathrm{O}$ trends from other sites argues that they primarily reflect paleoceanographic conditions. Cibicidoides $\delta^{13} \mathrm{C}$ compositions, which are significantly less affected by diagenetic processes in sediments with negligible organic matter as at Site 803 , exhibit close similarity to records of the same age from other deep-sea sites. The good agreement between the 
Table 1 (continued).

\begin{tabular}{|c|c|c|c|c|c|c|c|c|c|c|c|c|c|}
\hline \multirow[b]{2}{*}{$\begin{array}{l}\text { Core, section, } \\
\text { interval }(\mathrm{cm})\end{array}$} & \multirow[b]{2}{*}{$\begin{array}{l}\text { Depth } \\
\text { (mbsf) }\end{array}$} & \multirow[b]{2}{*}{$\begin{array}{l}\text { Age } \\
\text { (Ma) }\end{array}$} & \multicolumn{2}{|c|}{ Cibicidoides spp. } & \multicolumn{5}{|c|}{ Mixed planktonic foraminifers } & \multicolumn{4}{|c|}{ Bulk carbonate } \\
\hline & & & $\delta^{18} \mathrm{O}$ & $\delta^{13} \mathrm{C}$ & $\mathrm{Sr} / \mathrm{Ca}$ & $\mathrm{Mg} / \mathrm{Ca}$ & ${ }^{87} \mathrm{Sr} /{ }^{86} \mathrm{Sr}$ & $\delta^{87} \mathrm{Sr}$ & Age & ${ }^{87} \mathrm{Sr} /{ }^{86} \mathrm{Sr} \quad \mathrm{F}$ & Percent insoluble & $\delta^{87} \mathrm{Sr}$ & Age \\
\hline $45 X-6,17-19$ & 417.37 & 29.70 & 1.77 & 0.23 & & & & & & & & & \\
\hline $46 \mathrm{X}-1,64-66$ & 419.94 & 29.81 & 2.05 & 0.68 & & & $0.707869 \pm 20$ & -168.95 & 30.8 & $* 0.707879 \pm 20$ & & -167.54 & 30.5 \\
\hline $46 \times-2,76-78$ & 421.56 & 29.88 & 1.62 & 0.55 & & & & & & & & & \\
\hline $46 X-3,65-67$ & 422.95 & 29.94 & 1.46 & 0.65 & & & & & & & & & \\
\hline $46 X-4,67-69$ & 424.48 & 30.01 & 1.75 & 0.71 & & & & & & & & & \\
\hline $46 \mathrm{X}-5,21-23$ & 425.51 & 30.17 & 1.56 & 0.38 & & & & & & & & & \\
\hline $47 \mathrm{X}-1,26-28$ & 429.26 & 30.69 & 1.98 & 0.61 & 1.33 & 2.96 & $0.707880 \pm 20$ & -167.40 & 30.5 & $0.707895 \pm 25$ & 18.7 & -166.13 & 30.2 \\
\hline $47 X-2,86-88$ & 431.36 & 30.98 & 1.59 & 0.64 & & & & & & & & & \\
\hline $47 X-3,77-79$ & 432.77 & 31.17 & 1.83 & 0.39 & 1.27 & 2.67 & $0.707880 \pm 20$ & -167.40 & 30.5 & & & & \\
\hline $47 X-4,34-36$ & 433.85 & 31.32 & 1.27 & 0.07 & & & & & & & & & \\
\hline $47 X-5,66-68$ & 435.66 & 31.58 & 1.78 & 0.23 & & & & & & & & & \\
\hline $48 X-1,24-26$ & 438.84 & 32.02 & 1.66 & 0.72 & & & & & & & & & \\
\hline $48 X-2,22-24$ & 440.32 & 32.05 & 1.48 & 0.71 & & & & & & & & & \\
\hline $48 X-3,102-104$ & 442.62 & 32.09 & 1.65 & 0.20 & & & & & & & & & \\
\hline $48 \times-4,64-66$ & 443.74 & 32.11 & 1.52 & 0.43 & 1.17 & 2.78 & $0.707840 \pm 20$ & -173.04 & 31.9 & & & & \\
\hline $49 X-1,19-21$ & 447.99 & 32.19 & 1.73 & 0.55 & & & & & & $0.707805 \pm 23$ & 18.2 & -178.83 & 33.3 \\
\hline $49 \times-2,65-67$ & 449.95 & 32.23 & 1.70 & 0.42 & & & & & & & & & \\
\hline $49 X-3,37-39$ & 451.17 & 32.25 & 1.46 & 0.72 & & & & & & & & & \\
\hline $49 \times-4,49-51$ & 452.79 & 32.28 & 1.78 & 0.48 & & & & & & & & & \\
\hline $50 \times-2,50-52$ & 459.50 & 32.40 & 1.47 & 0.80 & & & & & & & & & \\
\hline $50 \times-3,21-23$ & 460.71 & 32.43 & 1.25 & 0.73 & & & & & & & & & \\
\hline $50 X-4,84-86$ & 462.84 & 32.47 & 1.99 & 0.78 & & & & & & & & & \\
\hline $51 X-1,67-69$ & 467.87 & 32.56 & 1.84 & 0.72 & & & & & & $0.707749 \pm 9$ & 20.5 & -186.72 & 35.2 \\
\hline $51 X-1,67-69$ & 467.87 & 32.56 & & & & & $0.707852 \pm 20$ & -171.35 & 31.4 & ${ }^{*} 0.707846 \pm 20$ & & -172.20 & 31.7 \\
\hline $51 X-2,9-11$ & 468.79 & 32.57 & 1.66 & 0.35 & & & & & & & & & \\
\hline $52 X-1,58-60$ & 477.48 & 32.75 & 1.81 & 0.99 & & & & & & & & & \\
\hline $52 X-2,86-88$ & 479.26 & 32.77 & 1.64 & 0.80 & & & & & & & & & \\
\hline $52 X-3,9-11$ & 479.99 & 32.78 & 1.43 & 0.82 & & & & & & & & & \\
\hline $53 X-1,73-75$ & 487.33 & 33.28 & 1.43 & 0.66 & 1.16 & 3.01 & & & & & & & \\
\hline $53 X-2,92-94$ & 489.02 & 33.41 & 1.68 & 0.70 & & & & & & & & & \\
\hline $53 \mathrm{X}-3,73-75$ & 490.33 & 33.51 & 1.50 & 0.98 & & & $0.70782 \pm 20$ & -175.86 & 32.50 & $0.707743 \pm 27$ & 22.6 & -187.57 & 35.5 \\
\hline $54 X-1,63-65$ & 496.93 & 34.01 & 1.64 & 0.78 & & & & & & & & & \\
\hline $54 X-2,77-79$ & 498.57 & 34.13 & 2.55 & 1.06 & & & & & & & & & \\
\hline $54 X-3,95-97$ & 500.25 & 34.26 & 1.37 & 0.86 & & & & & & & & & \\
\hline $54 X-4,7-9$ & 500.87 & 34.30 & 1.71 & 1.15 & & & & & & & & & \\
\hline $55 X-1,105-107$ & 507.05 & 34.70 & 1.65 & 0.88 & 1.22 & 3.48 & $0.70776 \pm 20$ & -184.33 & 34.65 & & & & \\
\hline $55 X-2,34-36$ & 507.84 & 34.74 & 1.55 & 0.78 & & & & & & & & & \\
\hline $55 X-3,71-73$ & 509.71 & 34.82 & 1.59 & 0.69 & & & & & & & & & \\
\hline $55 X-4,18-20$ & 510.68 & 34.86 & 1.88 & 0.66 & & & & & & $0.707737 \pm 24$ & 29.1 & -188.42 & 35.6 \\
\hline $56 \mathrm{X}-2,108-110$ & 518.18 & 35.20 & 2.13 & 0.83 & 1.22 & 3.34 & $0.70775 \pm 20$ & -185.74 & 35.00 & & & & \\
\hline $57 \mathrm{X}-1,50-52$ & 525.80 & 35.52 & 2.02 & 1.17 & 1.31 & 3.16 & $0.70775 \pm 20$ & -185.74 & 35.00 & $0.707766 \pm 21$ & 23.3 & -184.33 & 34.6 \\
\hline $57 X-2,68-70$ & 527.48 & 35.59 & 1.52 & 0.91 & & & & & & & & & \\
\hline $57 X-3,117-119$ & 529.47 & 35.67 & 2.17 & 1.22 & & & & & & & & & \\
\hline $58 \mathrm{X}-1,32-36$ & 534.94 & 35.90 & 1.86 & 1.51 & & & & & & & & & \\
\hline $59 \times-1,74-76$ & 545.04 & 36.80 & 0.75 & 0.81 & & & & & & & & & \\
\hline $59 \times-2,20-22$ & 546.00 & 36.81 & 0.60 & 0.62 & & & & & & & & & \\
\hline $60 \times-1,79-81$ & 554.79 & 36.90 & 0.63 & 0.99 & & & & & & & & & \\
\hline
\end{tabular}

Notes: $\mathrm{Sr} / \mathrm{Ca}$ and $\mathrm{Mg} / \mathrm{Ca}$ ratios in $\mathrm{mM} / \mathrm{M}$. An asterisk $\left({ }^{*}\right)$ indicates that analysis of bulk carbonate was performed at Washington University. Estimated sediment ages are from the chemostratigraphy discussed in the text.

stable isotopic records of the various sites is used below to refine the biostratigraphy and infer paleoceanographic conditions at Site 803 .

\section{RESULTS AND DISCUSSION}

\section{Sr-isotope Results}

The ${ }^{87} \mathrm{Sr} /{ }^{86} \mathrm{Sr}$ ratios and oxygen and carbon isotope data are listed in Table 1. Planktonic foraminifer ${ }^{87} \mathrm{Sr} /{ }^{86} \mathrm{Sr}$ ratios of Site 803 consistently increase with decreasing sample depth and age (Fig. 2). This pattern is typical of deep-sea sedimentary sequences of this age that have not been extensively affected by reworking or dissolution and reprecipitation processes (Hess et al., 1989). In spite of the small number of foraminifer samples, it is apparent that the increase in ${ }^{87} \mathrm{Sr} /{ }^{86} \mathrm{Sr}$ ratios is greater in the upper Oligocene part of the section than in the lower Oligocene, which is analogous to that observed at other deep-sea sequences (Hess et al., 1989). Although the general trend in bulk carbonate ${ }^{87} \mathrm{Sr} /{ }^{86} \mathrm{Sr}$ ratios is similar, several reversals are present, and ratios for the most part are about the same or lower than those of foraminifers.
Ages estimates for sediments as a function of depth based on Site $803^{87} \mathrm{Sr} /{ }^{86} \mathrm{Sr}$ and using the $\mathrm{Sr}$ isotope-age equations of Hess et al. (1989) are shown in Figure 2B. The solid line represents sediment ages based on planktonic foraminifer and nannofossil datums in Table 2 (Leckie, this volume; Backman, this volume) and are tied to the magnetostratigraphic scheme of Berggren et al. (1985). Estimated ages based on planktonic foraminifer ${ }^{87} \mathrm{Sr} /{ }^{86} \mathrm{Sr}$ ratios at 313 and 318 mbsf are in good agreement with biostratigraphic ages, indicating that sediments at this level are lowermost Miocene. The only instance when planktonic foraminifer and bulk carbonate ${ }^{87} \mathrm{Sr} /{ }^{86} \mathrm{Sr}$ yield significantly younger sediment ages than those inferred by biostratigraphy is for samples in the interval from about 380 to $391 \mathrm{mbsf}$. Reworking of younger microfossils into older sediments could explain the younger ages, but no micropaleontological evidence exists to support this scenario (Leckie, this volume). Planktonic foraminifer ${ }^{87} \mathrm{Sr} /{ }^{86} \mathrm{Sr}$ ratios exhibit little or no variation in the interval from 404 to $433 \mathrm{mbsf}$, considering the analytical uncertainty in the measurements. Bulk carbonate samples in this interval are close to foraminifer values, suggesting that they may reflect contemporaneous seawater 


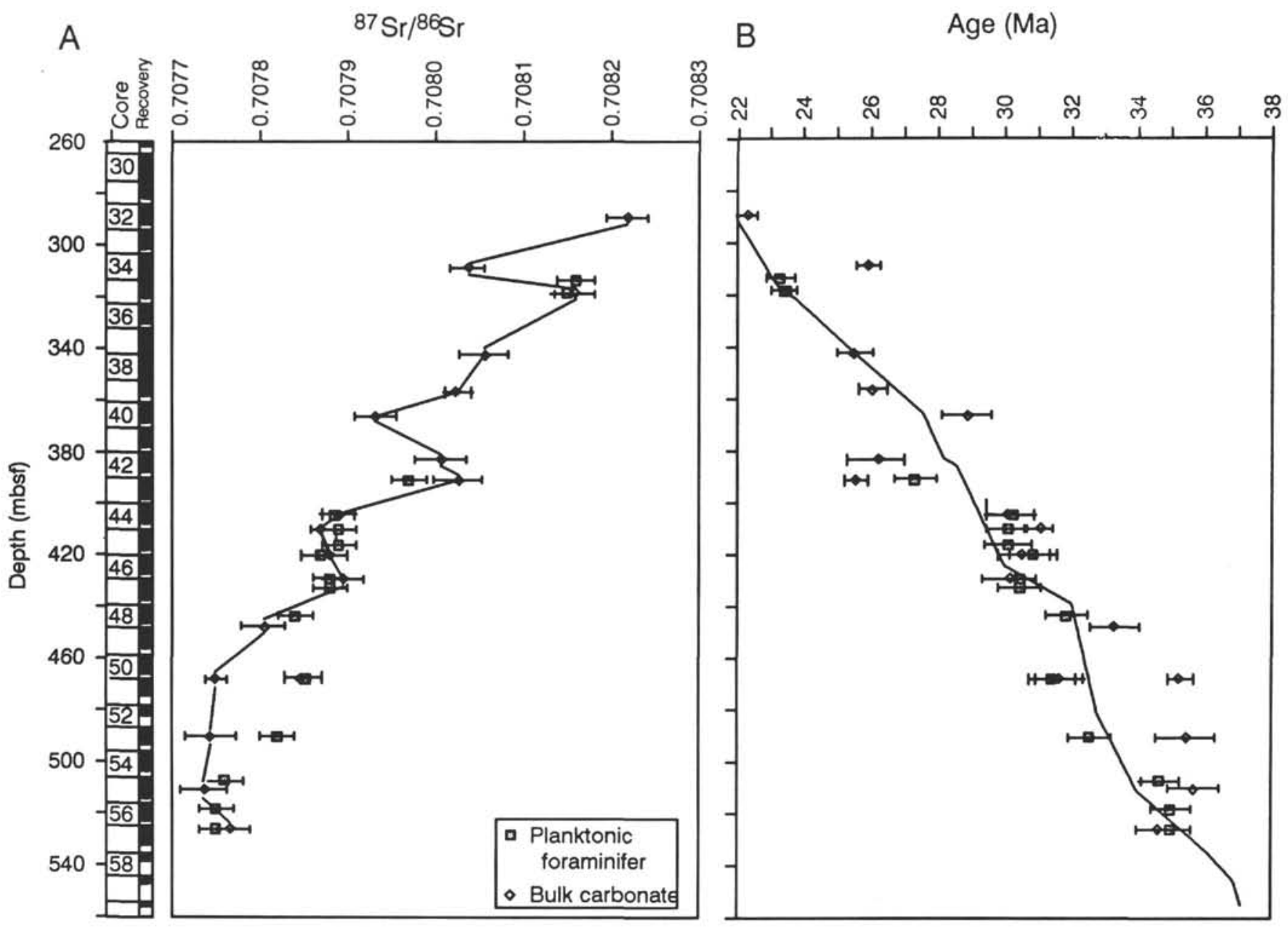

Figure 2. A. ${ }^{87} \mathrm{Sr} /{ }^{86} \mathrm{Sr}$ ratios of mixed planktonic foraminifer and bulk carbonate samples plotted vs. depth in the sediment at Hole $803 \mathrm{D}$. The small horizontal line through the data points represents the standard deviation of the measurements. The solid line connects bulk carbonate data. B. Age vs. depth plot of the Oligocene sections cored using $\mathrm{Sr}$ isotopes and biostratigraphic events at Hole 803D. The solid line is interpolated between the foraminifer and nannofossil datums (Leckie, this volume; Backman, this volume). The ages of Site $803^{87} \mathrm{Sr} /{ }^{86} \mathrm{Sr}$ samples were estimated using the $\mathrm{Sr}$-isotope-age equations of Hess et al. (1989). The small horizontal line through the data points represents uncertainty in estimated ages, resulting from the standard deviation of the measurement.

${ }^{87} \mathrm{Sr} /{ }^{86} \mathrm{Sr}$ to a large extent. However, estimated ages based on the Sr-isotope-age equation of Hess et al. (1989) would indicate that this thickness of sediments was deposited between about 30 and $30.5 \mathrm{Ma}$. We suggest as a possible explanation a low rate of ${ }^{87} \mathrm{Sr} /{ }^{86} \mathrm{Sr}$ change from about 28 to $30.5 \mathrm{Ma}$, based on our examination of the data of Sites 516 (Hess et al., 1989) and 522 (Miller et al., 1988). The apparent pattern of isotopic changes in this time interval may also be complicated by reduced sedimentation at most deep-sea sites, which is discussed in more detail below. At Hole 803D biostratigraphic control in this part of the section is poor, as provided by one calcareous data point, the last appearance datum (LAD) of Chiloguembelina cubensis, which has an assigned age of $30 \mathrm{Ma}$ (Berggren et al., 1985). Leckie (this volume) marks this level as the last "common" abundance of this taxon ( $424 \mathrm{mbsf}$ ) because he found specimens of this species higher up in the section into upper Oligocene sediments. Moreover, biostratigraphic data suggest that a hiatus or interval of reduced sedimentation may exist between 435 and 428 mbsf (Leckie, this volume). In this interval, about $1.5 \mathrm{~m}$.y. of the record could be represented. Planktonic foraminifer ${ }^{87} \mathrm{Sr} /{ }^{86} \mathrm{Sr}$ ratios at and near this level do not conflict with this interpretation. In the lower Oligocene part of the section, inferred sediment ages from planktonic foraminifer ${ }^{87} \mathrm{Sr} /{ }^{86} \mathrm{Sr}$ do not deviate significantly from those estimated from the biostratigraphy.

\section{Stable Isotope Results}

Refinement of the stratigraphy of the Oligocene section at Site 803 can be achieved with the integration of the stable isotope records. The $\delta^{18} \mathrm{O}$ and $\delta^{13} \mathrm{C}$ records of Cibicidoides relative to sediment depth are shown in Figure 3. These records are compared with those of Site 522 in Figure 4 and Site 77 in Figure 5. Correlation with the isotopic results of Site 522, which have been tied to the GPTS, permits more accurate age assignments. Resulting ages are, for the most part, in good agreement with the biostratigraphy (Fig. 3C). Estimated sediment ages for Site 77 are based on planktonic foraminifer datums (Keller, 1983, and pers. comm., 1991), with ages assigned according to the chemobiostratigraphy of Site 803.

The ubiquitous early Oligocene event of high $\delta^{18} \mathrm{O}$ values has been reported in sediments normally magnetized in Chron $\mathrm{C} 13 \mathrm{~N}$ and has been dated between 35.9 and $35.7 \mathrm{Ma}$ (Oberhänsli and Toumarkine, 1985; Miller et al., 1988; Barrera and Huber, 1991; Barrera et al., 1991). The $\delta^{18} \mathrm{O}$ event coincides with an increase in benthic foraminifer $\delta^{13} \mathrm{C}$ values that at Site 522 has been estimated to occur between about 35.3 and $35.9 \mathrm{Ma}$ (Fig. 4; Miller et al., 1988). At Hole $803 \mathrm{D}$, the early Oligocene $\delta^{18} \mathrm{O}$ increase of about $1.5 \%$ occurs in sediments between 545 and $535 \mathrm{mbsf}$, indicating that the upper level 
Table 2. Ages and depths of foraminifer and nannofossil datums from Site 803.

\begin{tabular}{lcc}
\hline \multicolumn{1}{c}{ Datum } & $\begin{array}{c}\text { Age } \\
\text { (Ma) }\end{array}$ & $\begin{array}{c}\text { Depth } \\
\text { (mbsf) }\end{array}$ \\
\hline FO Paragloborotalia kugleri & 23.7 & $319.50-322.00$ \\
LO Sphenolitus ciperoensis & 25.5 & $340.90-342.50$ \\
LO Paragloborotalia pseudokugleri & 26.3 & $360.66-361.82$ \\
LO Sphenolitus distentus & 27.6 & $365.20-366.20$ \\
LO Globorotalia opima opima & 28.2 & $381.24-384.78$ \\
LO Sphenolitus predistentus & 28.6 & $385.70-386.20$ \\
LO Chiloguembelina & 30.0 & $422.81-425.81$ \\
FO Globigerina angulisuturalis & 31.6 & $435.48-436.20$ \\
FO Globorotalia opima opima & 32.7 & $477.45-480.56$ \\
LO "Turborotalia" ampliapertura & 32.8 & $480.56-481.42$ \\
LO Pseudohastigerina spp. & 34.0 & $502.92-506.63$ \\
LO Reticulofenestra umbilica & 33.8 & $511.40-516.50$ \\
LO Ellipsolithus formosa & 34.9 & $522.70-525.80$ \\
LO Discoaster saipanensis & 36.7 & $530.60-534.70$ \\
LO Discoaster barbadiensis & 37.1 & $535.30-545.10$ \\
LO Turborotalia cerroazulensis & 36.6 & $535.86-544.74$ \\
LO Hantkenina spp. & 36.6 & $535.86-544.74$ \\
\hline
\end{tabular}

Notes: $\mathrm{FO}=$ first occurrence and $\mathrm{LO}=$ last occurrence Foraminifer datums from Leckie (this volume), and nannofossil datums from Backman (this volume). We found foraminifer datums in better agreement with the stable isotope stratigraphy of Site 803 than nannofossil datums.

cannot be older than $35.9 \mathrm{Ma}$ (Fig. 3). An increase in $\delta^{13} \mathrm{C}$ values is apparent in sediments between about 535 and $525 \mathrm{mbsf}$, providing an estimate for these sediments of approximately 35.9 to $35.3 \mathrm{Ma}$. These results suggest that the LAD of the planktonic foraminifer Pseudohastigerina spp. (at about 504 mbsf at Hole 803D; Leckie, this volume) in the equatorial Pacific is older than the age of $34 \mathrm{Ma}$ assigned by Berggren et al. (1985) and certainly younger than the age of 35.6 Ma inferred by Hess et al. (1989) from the Sr-isotope data of Site 77 and DSDP Site 292.

In deep-sea sections, benthic foraminifer $\delta^{13} \mathrm{C}$ values begin to decrease at about $35 \mathrm{Ma}$, reaching low values in the late early and early late Oligocene (Fig. 4). The interval of $\delta^{13} \mathrm{C}$ minima roughly corresponds with one or possibly two excursions of high $\delta^{18} \mathrm{O}$ values observed in benthic foraminifer records from sediments deposited between 32 and $28 \mathrm{Ma}$. At Site 803, Cibicidoides $\delta^{13} \mathrm{C}$ decrease in the lower Oligocene and reach minima between 400 and $455 \mathrm{mbsf}$, corresponding to inferred ages between about 29 and $32 \mathrm{Ma}$ (Figs. 3 and 4 ). The $\delta^{18} \mathrm{O}$ values decrease slightly in the early Oligocene after the earliest Oligocene $\delta^{18} \mathrm{O}$ event and have, on average, higher values in the late Oligocene. The absence of an apparent $\delta^{18} \mathrm{O}$ maxima in the middle Oligocene of Site 803, unlike those observed in the deeper water Pacific Sites 77 and 574, may be partially a result of hiatuses or oceanographic conditions discussed below. Carbonate dissolution is noted at various levels within this interval (Leckie, this volume). Keller et al. (1987) have identified two widespread deepsea hiatuses estimated at 28.1-29.2 Ma (Hiatus PHaa) and 30.3-31.4 $\mathrm{Ma}$ (Hiatus $\mathrm{PHb}$ ). Intense dissolution and poor recovery characterize the early/late Oligocene boundary interval (Magnetochrons C11 and C10) at Sites 563 and 522 (Fig. 4). Therefore, age assignments in this interval at most sites are uncertain. Nevertheless, Pacific sites appear to have a relatively complete sedimentary record across the early-late Oligocene transition, probably reflecting either higher accumulation rates and/or a lowering of the carbonate compensation depth (CCD) (Van Andel et al., 1975; Keller et al., 1987).

Cibicidoides $\delta^{13} \mathrm{C}$ values increase sharply between $\sim 323$ and 321 mbsf and decline markedly just above this upper level (Figs. 3 and 4). The rise in $\delta^{13} \mathrm{C}$ coincides with an abrupt increase in $\delta^{18} \mathrm{O}$ values at many deep-sea sites that is not as well defined at Site 803. Good age controls in this part of the section are provided by foraminifer datums and $\mathrm{Sr}$-isotope ratios, which assign them an earliest Miocene age. The first appearance of Globorotalia kugleri (321 mbsf; Leckie, this volume), which marks the Oligocene/Miocene boundary (Berggren et al., 1985), occurred during the sharp increase in isotopic values. These events have been similarly correlated at Atlantic DSDP Sites 366, 529, 558, 563, and 567 (Miller and Fairbanks, 1985; Miller et al., 1988), implying that the first appearance of $G$. kugleri in tropical waters is synchronous across longitude and does not take place about 1.5 m.y. earlier in the equatorial Pacific than in the Atlantic, as suggested by Hess et al. (1989) from Sr-isotope data at Site 77.

\section{PALEOCEANOGRAPHIC INFERENCES}

Kennett and Stott (1990) have recently suggested, based on benthic foraminifer $\delta^{18} \mathrm{O}$ values from two sites in the southernmost Atlantic, that Eocene and Oligocene deep-water circulation may have been substantially different from that of the late Neogene. They proposed, based on the lower $\delta^{18} \mathrm{O}$ values of the deeper Site 690 $(\sim 2000 \mathrm{~m})$ relative to those in the shallower Site $689(\sim 1400 \mathrm{~m})$, that warm and saline deep waters produced in lower latitudes were capped by colder and less saline waters of Antarctic origin. A recently completed isotopic study of two other sites (ODP Sites 699 and 703) in the same area confirms these results and defines the presence of a colder water mass between 1500 and $2500 \mathrm{~m}$ during the Oligocene (Mead et al., in press). Barrera and Huber (1991) noted that after the earliest Oligocene $\delta^{18} \mathrm{O}$ shift, benthic foraminifer records at 2000$3000 \mathrm{~m}$ water depth from high-latitude sites are offset by $\sim 0.5 \%$ for those of lower latitude Pacific and Atlantic sites, and they suggested that lower latitude waters may have been mixtures of at least two sources. The isotopic data of Site 803 generated in this study, together with published isotopic records from deeper water equatorial Pacific sites, permit us to explore this possibility further and draw inferences regarding the characters of deep waters in this basin.

Closely located in the central equatorial Pacific, Sites 574 and 77 were at about 3200 and $2700 \mathrm{~m}$ water depth, respectively, during the earliest Oligocene, and about $500 \mathrm{~m}$ deeper in the late Oligocene (Miller and Thomas, 1985). In the early Miocene, Site 77 was at about $3800 \mathrm{~m}$ water depth (Woodruff and Savin, 1989). Oxygen and carbon isotope time series of Cibicidoides from the central equatorial Pacific sites in the Oligocene are very similar in trend and absolute values (see fig. 2 in Miller and Thomas, 1985), with only slightly higher $\delta^{18} \mathrm{O}$ in the deeper site. This indicates that water masses in this depth range had comparable chemical characters and histories. Assuming standard subsidence (Detrick et al., 1977), the Ontong Java Plateau Site 803 was bathed by waters about $800 \mathrm{~m}$ higher up in the water column and these apparently had characteristics different from those at Sites 77 and 574 at several times during the Oligocene and in the early part of the Miocene. Although Oligocene to early Miocene $\delta^{13} \mathrm{C}$ values in the Ontong Java Plateau and central Pacific are similar in pattern and magnitude, $\delta^{18} \mathrm{O}$ values exhibit significant differences (Fig. 5). The $\delta^{18} \mathrm{O}$ values of $0.6 \%$ $0.8 \%$ at both locations before $36 \mathrm{Ma}$ are followed by a maximum ${ }^{18} \mathrm{O}$ enrichment to values of about $1.8 \%$ at Sites 77 and 574 and $\sim 2.2 \%$ at Site 803 . Thus, the enrichment is greater by about $0.4 \%$ at the shallower site. Higher values persisted at Site 803 until 34.5 $\mathrm{Ma}$, when they approach those of Site 77 (Fig. 5). In the interval from 34 to $28.5 \mathrm{Ma}, \delta^{18} \mathrm{O}$ values at Sites 77 and 803 overlap, though there are high-amplitude fluctuations suggestive of variable oceanographic conditions, which are also reflected in the $\delta^{13} \mathrm{C}$ data. The trend in this part of the section is of increasing $\delta^{18} \mathrm{O}$ values and is interrupted at about $28.5 \mathrm{Ma}$ in Site 77 and later at about 26.5 Ma at Site 803 . In the early Miocene from about 22 to $20.5 \mathrm{Ma}, \delta^{18} \mathrm{O}$ values at Site 803 are likewise substantially higher than at Site 77.

The apparent inversion in $\delta^{18} \mathrm{O}$ gradients in the earliest Oligocene and late Oligocene to early Miocene relative to modern patterns could be explained if waters below $2500 \mathrm{~m}$ in the equatorial Pacific were warmer and more saline than waters immediately above. Waters at shallower depths may have been mixed with colder waters from the northern or southern high latitudes, whereas the deeper waters may 


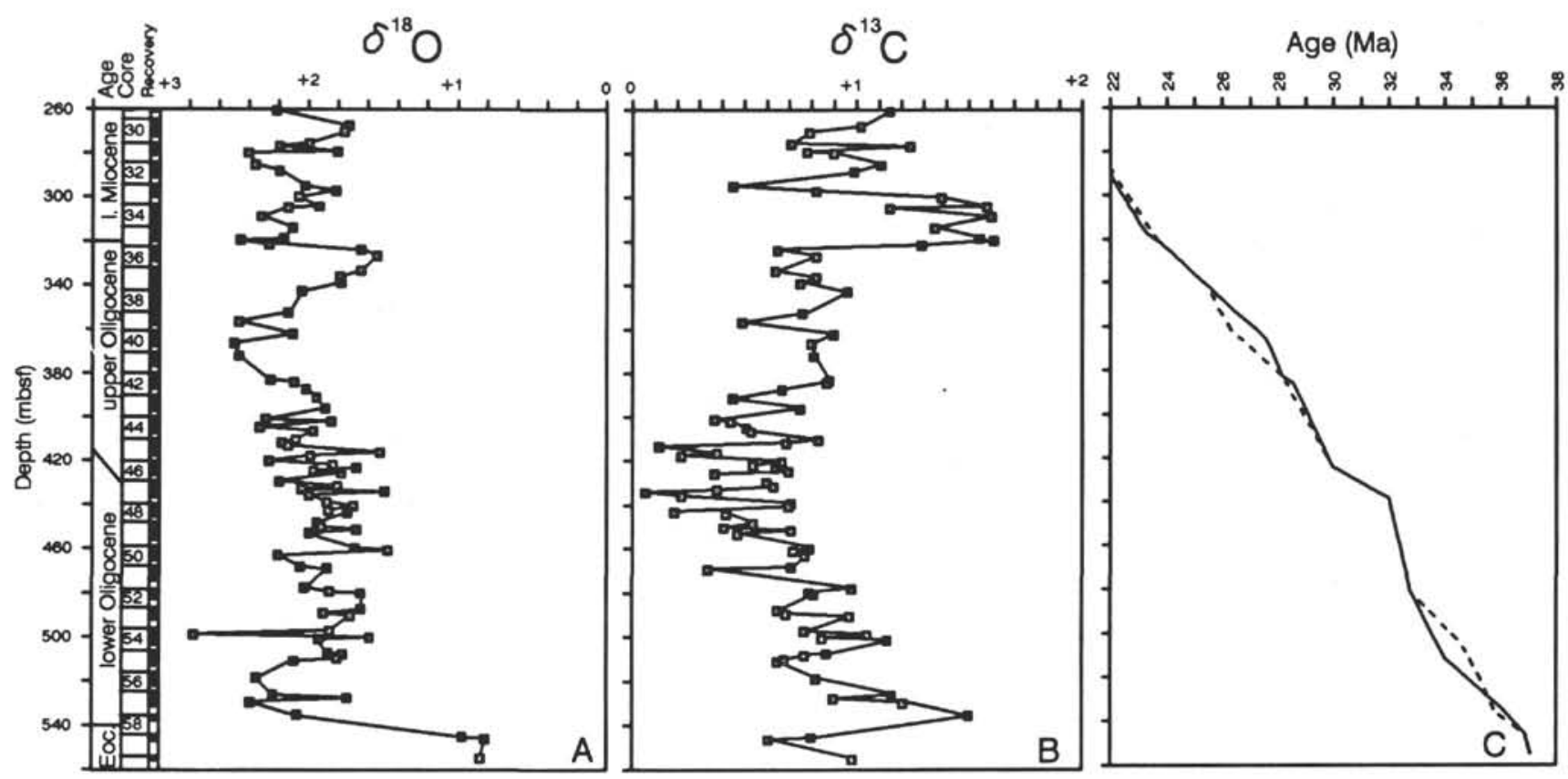

Figure 3. Oxygen isotope composition (A) and carbon isotope composition (B) of Cibicidoides spp. plotted vs. depth in the sediment. C. Age vs. depth plot of the Oligocene sections based on the chemobiostratigraphy. The dashed line represents deviations from the biostratigraphy (solid line) suggested by stable isotope stratigraphy. The middle Oligocene drawing of this line is uncertain because of dissolution in this interval at many deep-sea sites.

have been a mixture with lower latitude warm saline waters. Can other explanations be entertained for such patterns? We have no textural evidence that Cibicidoides calcite at Site 803 has been grossly affected by dissolution/reprecipitation processes. Moreover, diagenetic alteration with increasing burial and at higher temperatures than those where the foraminifers grew would tend to shift $\delta^{18} \mathrm{O}$ compositions in the negative direction, opposite to the observed pattern. The similarity of the isotopic records of Sites 77 and 574 also suggests that Cibicidoides $\delta^{18} \mathrm{O}$ values at these locations have not been greatly altered by diagenesis.

In the earliest Oligocene, some interesting differences are present in the $\delta^{18} \mathrm{O}$ patterns from the Pacific sites when compared with those from other locations. The $\delta^{18} \mathrm{O}$ trend at Site 803 mimics the pattern observed at Site 522 (paleodepth about $3000 \mathrm{~m}$ in the Oligocene) (Fig. 4), with high values close to $2.2 \%$ at the ${ }^{18} \mathrm{O}$ enrichment followed by a rapid but progressive depletion of more than $0.4 \%$. The $\delta^{18} \mathrm{O}$ compositions at these two sites in this interval are nearly as high as those observed in southern high-latitude sites (i.e., Sites 689 and 744; see fig. 11 in Barrera and Huber, 1991). In contrast, the sharp $\delta^{18} \mathrm{O}$ positive shift at Site 77 (as at Site 574 ) is permanent as it is followed by more or less similar values (Fig. 5). Carbonate dissolution present in the boundary transition at both Sites 77 and 574 (Keller, 1983; Saito, 1985) may lead to errors in age assignments that could account for the differences in the Pacific sites. This possibility cannot be ruled out until the transition at Sites 77 and 574 is examined in more detail. Alternatively, the earliest Oligocene $\delta^{18} \mathrm{O}$ shift may reflect a combination of ice-volume increase and lower temperatures, with colder waters bathing Site 803 .

Keigwin and Corliss (1986) estimated that increased continental ice accumulation had affected seawater $\delta^{18} \mathrm{O}$ composition by about $0.4 \%$ based on the $\delta^{18} \mathrm{O}$ change in tropical shallow-dwelling planktonic foraminifer species from upper Eocene to lower Oligocene sediments and the assumption that tropical surface-water temperatures had remained constant. It is not obvious from the biostratigraphic resolution of their data whether this ice-volume effect applies to either the earliest portion or most of the early Oligocene. No proof also exists that tropical surface waters were not colder in some areas in the early Oligocene. Nevertheless, if their assumptions and esti- mates are correct and the records of the equatorial Pacific are complete, the $\delta^{18} \mathrm{O}$ patterns at Sites 803 and 77 may represent greater cooling of waters at about $2000 \mathrm{~m}$ depth relative to deeper waters, with the shallower water nearly as cold as that at intermediate depths in the high latitudes. By this scenario, Pacific deeper water must have then cooled more than the shallower water just after about $35 \mathrm{Ma}$, and little of a persistent thermal/salinity gradient existed in the later part of the early Oligocene and into the early part of the late Oligocene. This also implies that high-latitude deep waters cooled significantly after the earliest Oligocene $\delta^{18} \mathrm{O}$ shift.

In the late Oligocene and early Miocene, the inversion in the $\delta^{18} \mathrm{O}$ gradient suggests that the deeper waters were warmer and more saline than waters above from about 28 to at least $26 \mathrm{Ma}$, and about 22 to $20.5 \mathrm{Ma}$ (Fig. 5). Unfortunately, at the deeper Sites 77 and 574, the record of the latest Oligocene to earliest Miocene is missing, as it is at many other deep-sea sites, because of a hiatus (Keller et al., 1987). However, comparison of the records of the Pacific sites and South Atlantic Sites 522 and 525 (Shackleton et al., 1984) indicate that deep waters, indeed, warmed considerably during this time interval. Woodruff and Savin (1989) noted that the interval from 20 to 21 Ma was the only time during the Miocene that benthic foraminifers from both shallow and deep waters in the North Pacific had markedly higher $\delta^{18} \mathrm{O}$ values than those from the South Pacific. It is also evident in their paleoceanographic reconstruction for the same time interval that Cibicidoides from deep waters in the equatorial Pacific were more ${ }^{18} \mathrm{O}$ depleted than those from depths shallower than about $2700 \mathrm{~m}$, similar to results presented here.

If deep water at the levels of Sites 77 and 803 resulted from the mixing of water masses with different origins, we would expect older waters more distant from their source to have lower ${ }^{13} \mathrm{C} /{ }^{12} \mathrm{C}$ ratios. This is because, as deep water travels away from its source or as it ages, it accumulates $\mathrm{CO}_{2}$ from the oxidation of ${ }^{13} \mathrm{C}$-depleted organic matter (Broecker and Peng, 1982). However, no apparent vertical $\delta^{13} \mathrm{C}$ gradients are present in the deep waters during the Oligocene (Figs. 4B and 5B) (Barrera and Huber, 1991; Mead et al., in press), indicating that the difference between the water-mass ages was small. It is also puzzling that, although the high benthic foraminifer $\delta^{18} \mathrm{O}$ values in the north Pacific at 20-23 Ma (Woodruff and Savin, 1989), discussed 

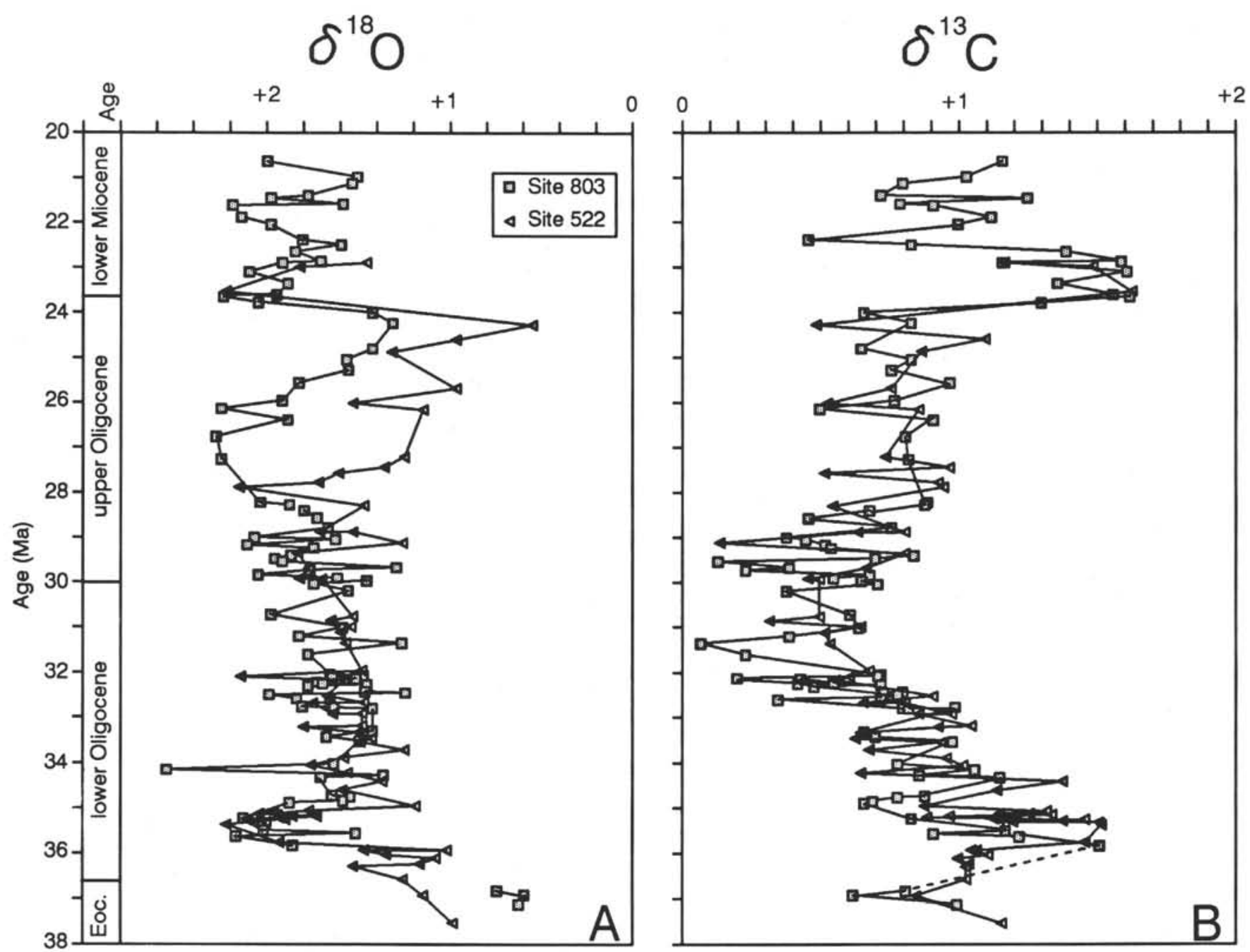

Figure 4. Correlation of $\delta^{18} \mathrm{O}(\mathbf{A})$ and $\delta^{13} \mathrm{C}(\mathbf{B})$ records of Cibicidoides spp. from Sites 522 and 803 . Site 522 stable isotopic values have been tied to the Geomagnetic Polarity Time Scale. Note the excellent correlation of these records, particularly in the earliest Oligocene and latest Oligocene to early Miocene. Sediment ages and isotopic data for Site 522 from Miller et al. (1988).

above, may suggest that these waters originated in the northern high latitudes, this is not supported by the benthic foraminifer $\delta^{13} \mathrm{C}$ data.

\section{SUMMARY AND CONCLUSIONS}

Stratigraphic information from strontium, oxygen, and carbon isotopic ratios has been integrated with nannofossil and planktonic foraminifer datums to refine the Oligocene to early Miocene chemostratigraphy of Site 803 . Sr-isotope results are based on analyses of mixed species of planktonic foraminifer and bulk carbonate samples. The ${ }^{87} \mathrm{Sr} /{ }^{86} \mathrm{Sr}$ ratios of bulk carbonate samples are, in most cases, less radiogenic than contemporaneous seawater. Estimated sediment ages based on planktonic foraminifer ${ }^{87} \mathrm{Sr} /{ }^{86} \mathrm{Sr}$ using the $\mathrm{Sr}$-isotopeage relation of Hess et al. (1989) are in moderately good agreement with biostratigraphic ages. Chronological resolution is significantly enhanced with the correlation of oxygen and carbon isotope records to those of the standard Oligocene section tied to the Geomagnetic Polarity Time Scale at Site 522 (Miller et al., 1988). Ages revised by this method and the published ages of planktonic foraminifer datums (Keller, 1983) are used to revise the Oligocene stratigraphy of Site 77 to correlate the Site 77 and 803 stable isotope records.

The ages of two planktonic foraminifer datums are revised. The last appearance of Pseudohastigerina spp. in the equatorial Pacific is older than the age of $34 \mathrm{Ma}$ assigned by Berggren et al. (1985) and younger than the $35.6 \mathrm{Ma}$. age inferred by Hess et al. (1989) from the Sr-isotope data of Sites 77 and 292. The first appearance of G. kugleri that marks the Oligocene/Miocene boundary is synchronous with its Atlantic occurrence, instead of appearing $1.5 \mathrm{~m}$.y. earlier in the Pacific (Hess et al., 1989). Estimated ages for Site 77 Oligocene sediments, based on the published planktonic foraminifer ${ }^{87} \mathrm{Sr} /{ }^{86} \mathrm{Sr}$ ratios (Hess et al., 1989), using the Sr-isotope-age relation of Hess et al. (1989), are significantly older ages than those estimated from the biostratigraphy or the stable isotope stratigraphy.

Comparison of the Cibicidoides stable isotope records of Sites 77 and 574 with paleodepths below $2500 \mathrm{~m}$ in the central equatorial Pacific, and of Site 803 at about $2000-\mathrm{m}$ paleodepth in the Ontong Java Plateau reveals inversions in the vertical $\delta^{18} \mathrm{O}$ gradient at several times during the Oligocene and early Miocene. The shallower water site had significantly higher $\delta^{18} \mathrm{O}$ values than the deeper water sites after the earliest Oligocene ${ }^{18} \mathrm{O}$ enrichment and before $34.5 \mathrm{Ma}$, in the late Oligocene from 27.5 to at least $25 \mathrm{Ma}$, and in the early Miocene from about 22.5 to $20.5 \mathrm{Ma}$. It is not possible to ascertain if the inferred $\delta^{18} \mathrm{O}$ inversion persisted in the latest Oligocene and into the early Miocene because the deeper sites have hiatuses spanning this interval. We interpret this pattern to reflect that waters at about 2000 $\mathrm{m}$ were cold and may have formed from mixing with colder waters originating in the northern or southern high-latitude regions. The deeper water was relatively warmer and may have been a mixture with 
warm saline waters from mid- or low-latitude regions. No apparent vertical $\delta^{13} \mathrm{C}$ gradient exists during the Oligocene, suggesting that the difference in the ages of these water masses was small.

\section{ACKNOWLEDGMENTS}

The comments of two anonymous reviewers helped to improve this manuscript. We thank the Ocean Drilling Program for providing samples, Dr. Tim Denison of Mobil Research and Development Corporation for providing ${ }^{87} \mathrm{Sr} /{ }^{86} \mathrm{Sr}$ analyses, and Drs. Lynn Walter and Ted Huston for elemental results. This research was supported by grants from USSAC for post-cruise research and NSF OCE-8800049 to E. Barrera.

\section{REFERENCES}

Baker, P.A., Gieskes, J.M., and Elderfield, H., 1982. Diagenesis of carbonates in deep-sea sediments - evidence from $\mathrm{Sr} / \mathrm{Ca}$ ratios and interstitial water dissolved $\mathrm{Sr}^{2+}$ data. J. Sediment. Petrol., 52:71-82.

Barrera, E., Barron, J., and Halliday, A., 1991. Strontium isotope stratigraphy of the Oligocene-lower Miocene section at Site 744, southern Indian Ocean. In Barron, J., Larsen, B., et al., Proc. ODP, Sci. Results, 119: College Station, TX (Ocean Drilling Program), 731-738.

Barrera, E., and Huber, B.T., 1991. Paleogene and early Neogene oceanography of the southern Indian Ocean: Leg 119 foraminifer stable isotope results. In Barron, J., Larsen, B., et al., Proc. ODP, Sci. Results, 119: College Station, TX (Ocean Drilling Program), 693-717.

Belanger, P.E., Curry, W.B., and Matthews, R.K., 1981. Core-top evaluation of benthic foraminiferal isotopic ratios for paleoceanographic interpretations. Palaeogeogr., Palaeoclimatol., Palaeoecol., 33:205-220.

Berggren, W.A., Kent, D.V., and Van Couvering, 1985. Paleogene geochronology and chronostratigraphy. In Snelling, N.J. (Ed.), The Chronology of the Geologic Record. Mem. Geol. Soc. London, 10:141-195.

Brass, G.W., Southam, J.R., and Peterson, W.H., 1982. Warm saline bottom water in the ancient ocean. Nature, 296:620-623.

Broecker, W.S., and Peng, T.H., 1982. Tracers in the Sea: Palisades, NY (Eldigio).

Burke, W.H., Denison, R.E., Hetherington, E.A., Koepnick, R.B., Nelson, H.F., and Otto, J.B., 1982. Variation of seawater ${ }^{87} \mathrm{Sr} /{ }^{86} \mathrm{Sr}$ throughout Phanerozoic time. Geology, 10:516-519.

Capo, R.J., and DePaolo, D.J., 1988, Seawater strontium isotopic variations from 2.5 million years ago to the present. Science, 249:51-55.

Carpenter, S., and Lohmann, K.C, in press. Sr/Mg ratios of modern marine calcite: empirical indicators of ocean chemistry and precipitation rate. Geochim. Cosmochim. Acta, 56.

Chamberlain, T.C., 1906. On a possible reversal of deep-sea circulation and its influence on geologic climates. J. Geol., 14:363-373.

Delaney, M.L., Bé, A.W.H., and Boyle, E.A., 1985. Li, Sr, Mg, and $\mathrm{Na}$ in foraminiferal calcite shells from laboratory culture, sediment traps, and sediment cores. Geochim. Cosmochim. Acta, 49:1327-1341.

DePaolo, D.J., 1986. Detailed record of the Neogene $\mathrm{Sr}$ isotopic evolution of seawater from DSDP Site 590B. Geology, 14:103-106.

DePaolo, D.J., and Finger, K.L., 1991. High-resolution strontium-isotope stratigraphy and biostratigraphy of the Miocene Monterey Formation, central California. Geol. Soc. Am. Bull., 103:112-124.

DePaolo, D.J., and Ingram, B.L., 1985. High-resolution stratigraphy with strontium isotopes. Science, 227:938-941.

Detrick, R.S., Sclater, J.G., and Thiede, J., 1977. The subsidence of aseismic ridges. Earth Planet. Sci. Lett., 34:185-198.

Elderfield, H., 1986. Strontium isotope stratigraphy. Palaeogeogr, Palaeoclimatol., Palaeoecol., 57:71-90.

Elderfield, H., and Gieskes, J.M., 1982. Sr isotopes in interstitial waters of marine sediments from Deep Sea Drilling Project cores. Nature, 300:493-497.

Elderfield, H., Gieskes, J.M., Baker, P.A., Oldfield, R.K., Hawkesworth, C.J., and Miller, R., $1982 .{ }^{87} \mathrm{Sr} /{ }^{86} \mathrm{Sr}$ and ${ }^{18} \mathrm{O} /{ }^{16} \mathrm{O}$ ratios, interstitial water chemistry and diagenesis in deep-sea carbonate sediments of the Ontong Java Plateau. Geochim. Cosmochim. Acta, 46:2259-2268.

Gieskes, J.M., Elderfield, H., and Palmer, M., 1986. Strontium and its isotopic composition in interstitial waters of marine carbonate sediments. Earth Planet. Sci. Lett., 77:229-235.

Graham, D.W., Bender, M.L., Williams, D.F., and Keigwin, L.D., Jr., 1982. Strontium-calcium ratios in Cenozoic planktonic foraminifera. Geochim. Cosmochim. Acta, 46:1281-1292.
Graham, D.W., Corliss, B.H., Bender, M.L., and Keigwin, L.D., 1981. Carbon and oxygen isotopic disequilibria of Recent benthic foraminifera. Mar. Micropaleontol., 6:483-497.

Hammond, S.K., Kroenke, L.W., Theyer, F., and Keeling, D.L., 1975. Late Cretaceous and Paleogene paleolatitudes on the Ontong Java Plateau. Nature, 255:46-47.

Hess, J., Bender, M.L., and Schilling, J.G., 1986. Evolution of the ratio of strontium-87 to strontium-86 in seawater from Cretaceous to Present. Science, 231:979-984.

Hess, J., Stott, L.D., Bender, M.L., Kennett, J.P., and Schilling, J.G., 1989. The Oligocene marine microfossil record: age assessment using strontium isotopes. Paleoceanography, 4:655-679.

Katz, A., Sass, E., Starinsky, A., and Holland, H.D., 1972. Strontium behavior in the aragonite-calcite transformation: an experimental study at $40-98^{\circ} \mathrm{C}$. Geochim. Cosmochim. Acta, 36:481-496.

Keigwin, L., 1980. Paleoceanographic change in the Pacific at the EoceneOligocene boundary. Science, 287:722-725.

Keigwin, L., and Corliss, B., 1986. Stable isotopes in late middle Eocene to Oligocene foraminifera. Geol. Soc. Am. Bull., 97:335-345.

Keigwin, L., and Keller, G., 1984. Middle Oligocene climatic change from equatorial Pacific DSDP Site 77. Geology, 12:16-19.

Keller, G., 1983. Biochronology and paleoclimatic implications of middle Eocene to Oligocene planktic foraminifera faunas. Mar. Micropaleontol., $7: 463-486$,

Keller, G., Herbert, T., Dorsey, R., D'Hondt, S., Johnson, M., and Chi, W.R., 1987. Global distribution of late Paleogene hiatuses. Geology, 15:199-203.

Kennett, J.P., and Stott, L.D., 1990. Proteus and proto-oceanus: Paleogene oceans as revealed from Antarctic stable isotopic results: ODP Leg 113. In Barker, P.F., Kennett, J.P., et al., Proc. ODP, Sci. Results, 113: College Station, TX (Ocean Drilling Program), 865-880.

Koepnick, R.B., Denison, R.E., Burke, W.H., Hetherington, E.A., and Dahl, D.A., 1990. Construction of the Triassic and Jurassic portion of the phanerozoic curve of seawater ${ }^{87} \mathrm{Sr} /{ }^{86} \mathrm{Sr}$. Chem. Geol., Isotope Geosci. Sec., 80:327-349.

Mead, G.A., Hodell, D.A., and Ciesielski, P.F., in press. Late Eocene to early Oligocene vertical oxygen isotopic gradients in the South Atlantic: implications for warm saline deep water. Palaeogeogr., Palaeoclimatol., Palaeoecol.

Miller, K.G., Aubry, M.P., Khan, M.J., Melillo, A.J., Kent, D.V., and Berggren, W.A., 1985. Oligocene to Miocene biostratigraphy, magnetostratigraphy, and isotopic stratigraphy of the Western North Atlantic. Geology, 13:257-261.

Miller, K.G., and Fairbanks, R.G., 1985. Oligocene-Miocene global carbon and abyssal circulation changes. In Sundquist, E., and Broecker, W.S. (Eds.), The Carbon Cycle and Atmospheric $\mathrm{CO}_{2}$ : Natural Variations Archean to Present. Am. Geophys. Union, 469-486.

Miller, K.G., Fairbanks, R.G., and Mountain, G.S., 1987. Tertiary oxygen isotope synthesis, sea level history, and continental margin erosion. Paleoceanography, 2:1-19.

Miller, K.G., Feigenson, M.D., Kent, D.V., and Olsson, R.K., 1988. Upper Eocene to Oligocene isotope $\left({ }^{87} \mathrm{Sr} /{ }^{86} \mathrm{Sr}, \delta^{18} \mathrm{O}, \delta^{13} \mathrm{C}\right)$ standard section, Deep Sea Drilling Project Site 522. Paleoceanography, 3:223-233.

Miller, K.G., and Thomas, E., 1985. Late Eocene to Oligocene benthic foraminiferal isotopic record, Site 574, equatorial Pacific. In Mayer, L., Theyer, F., Thomas, E., et al., Init. Repts. DSDP, 85: Washington (U.S. Govt. Printing Office), 771-777.

Morrow, D.W., and Mayers, J.W., 1978. Simulation of limestone diagenesisa model based on strontium depletion. Can. J. Earth Sci., 15:376-396.

Oberhänsli, H., McKenzie, J., Toumarkine, M., and Weissert, 1984. A paleoclimatic and paleoceanographic record of the Paleogene in the Central South Atlantic (Leg 73, Sites 522, 523, and 524). In Hsü, K.J., LaBrecque, J.L., et al., Init. Repts. DSDP, 73: Washington (U.S. Govt. Printing Office), 737-747.

Oberhänsli, H., and Toumarkine, M., 1985. The Paleogene oxygen and carbon isotope history of Sites 522, 523, and 524 from the central South Atlantic. In Hsü, K.J., and Weissert, H.J. (Eds.), South Atlantic Paleoceanography: New York (Cambridge Univ. Press), 125-147.

Palmer, M., and Elderfield, H., 1985. Sr isotope composition of seawater over the past 75 Myr. Nature, 314:526-528.

Podosek, F.A., Zinner, E.K., MacPherson, G.J., Lundberg, L.L., Brannon, J.C., and Fahley, A.J., 1991. Correlated study of initial ${ }^{87} \mathrm{Sr}{ }^{86} \mathrm{Sr}$ and $\mathrm{Al}-\mathrm{Mg}$ isotopic systematics and petrologic properties in a suite of refractory inclusions from the Allende meteorite. Geochim. Cosmochim. Acta, 55:1083-1110.

Poore, R.Z., and Matthews, R.K., 1984. Late Eocene-Oligocene oxygen- and carbon-isotope record from South Atlantic Ocean, Deep Sea Drilling 
Project Site 522. In Hsü, K.J., LaBrecque, J.L., et al., Init. Repts. DSDP, 73: Washington (U.S. Govt. Printing Office), 725-735.

Richter, F.M., and DePaolo, D.J., 1987. Numerical models for diagenesis and the Neogene $\mathrm{Sr}$ isotopic evolution of seawater from DSDP Site 590B. Earth Planet. Sci. Lett., 83:27-38.

Saito, T., 1985. Planktonic foraminiferal biostratigraphy of eastern equatorial Pacific sediments, Deep Sea Drilling Project Leg 85. In Mayer, L., Theyer, F., Thomas, E., et al., Init. Repts. DSDP, 85: Washington (U.S. Govt. Printing Office), 621-653.

Shackleton, N.J., and Hall, M.A., 1984. Carbon isotope data from Leg 114 sediments. In Moore, T.C., Jr., Rabinowitz, P.D., et al., Init. Repts. DSDP, 74: Washington (U.S. Govt. Printing Office), 613-619.
Shipboard Scientific Party, 1991. Site 803. In Kroenke, L.W., Berger, W.H., Janecek, T.R., et al., Proc. ODP, Init. Repts., 130: College Station, TX (Ocean Drilling Program), 101-176.

Van Andel, T.H., Heath, G.R., and Moore, T.L., Jr., 1975. Cenozoic tectonics, sedimentation and paleoceanography of the central equatorial Pacific. Geol. Soc. Am. Bull., 143:1-134.

Woodruff, F., and Savin, S.M., 1989. Miocene deepwater oceanography. Paleoceanography, 4:87-140.

Date of initial receipt: 2 December 1991

Date of acceptance: 22 June 1992

Ms 130B-022
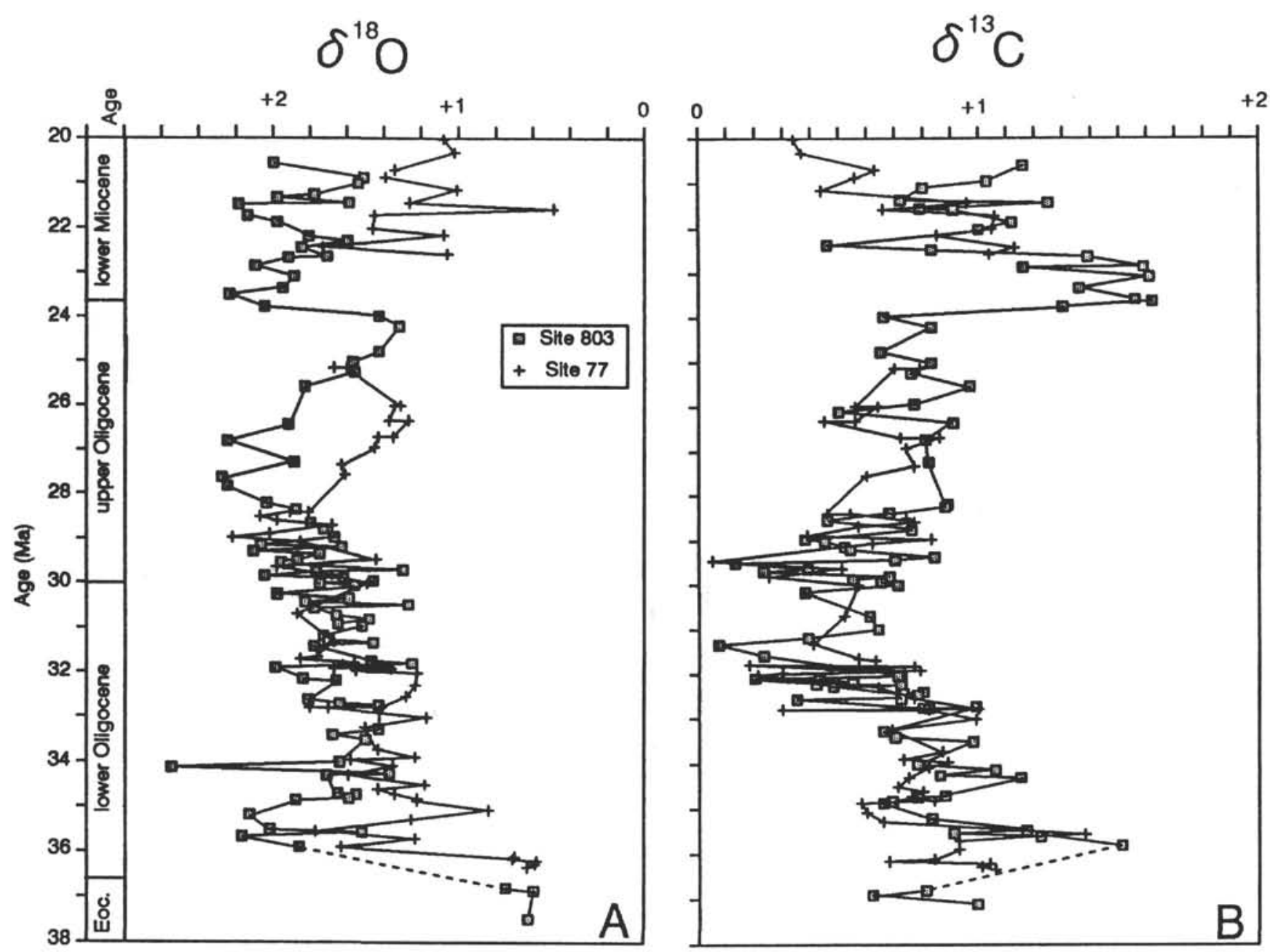

Figure 5. Comparison of oxygen isotopic compositions (A) and carbon isotopic compositions (B) of Cibicidoides spp. from Sites 77 and 803 . Note that $\delta^{18} \mathrm{O}$ values of Site 803 in the lowermost Oligocene and in the upper Oligocene are higher than at Site 77. Sediment ages for Site 77 are from planktonic foraminifer datums from Keller (1983). Site 77 data from Keigwin and Corliss (1986). 